\title{
EDITORIAL
}

\section{MORRER COM DIGNIDADE}

Todos nós, certo dia, faremos uma longa viagem sem retorno. A morte é sempre triunfante, imbativel e incombatível. Perseverante, nada prevalece contra ela. Às vezes, chega como um raio fulminante, que sidera e abate. Em outras ocasiōes vem corroendo o pobre corpo humano, metade viva arrastando metade morta. Espasmos, hemorragias, êmbolos e trombos, a maré-montante dos derrames e edemas cavitários, os cânceres de todas as espécies, a morte bem-vinda pela família, tudo isto nos acompanha e, muitas vezes, como nos diz mestre NAVA, sobra apenas um enterrinho barato, de defunto caro, com o pouco que sobrou da ganância terapêutica. No caso de uma embolia fatal, é como se "pulasse a rolha de uma garrafa de champanha ou, então, a tampa de ferro de um bueiro em dias de inundação". Dono de uma longa vivência humana, acompanho com tristeza a morte dos portadores de neoplasias, comidos e corroídos em vida até a sua última migalha. Elas possuem raizes mais fortes que as do solo. Fora de qualquer regra biológica, a célula neoplásica multiplica-se de maneira anárquica e, em certos casos, leva à podridão antes da morte. Kübler-Ross refere-nos, então, que tais pacientes precisam receber todo nosso apoio. No silêncio que vai além das palavras, eles saberão que este momento não deve ser nem assustador, nem doloroso, mas uma pacífica cessação do funcionamento do corpo. Observar a morte de um ser humano lembra-nos uma estrela cadente: um dos milhões de luzeiros em um vasto céu, que se inflama por um breve momento, a fim de desaparecer para sempre, dentro da noite interminável. Ser terapêuta para um paciente agonizante nos faz cientes da singularidade de cada indivíduo neste vasto oceano de humanidade. Nascer e morrer são termos conhecidos da equação da vida. Às vezes, nosso corpo se cansa e já não pode trabalhar. Nosso coração cessa de bater e nós adormecemos, mas a pessoa real continua viva. Face à aproximação da morte, o paciente pede o auxílio do médico com o simples olhar. Somente quem dignifica a morte, valoriza a vida. $\mathbf{O}$ paciente agonizante não deve sofrer, nem física, nem emocionalmente. Este é o fulcro da questão. Suas necessidades e anseios não mudaram através dos séculos: apenas mudou nossa habilidade para atendê-los, quando se aproximam os momentos derradeiros. Nada mais somos do que a sombra de uma sombra, já o disse alguém, com grande sabedoria e só uma vida bem vivida pode ensinar a viver. $\mathrm{E}$ só vive bem, com Deus e sua consciência, quem se convence daquela assertiva inicial. Àquele que vai morrer, podemos e devemos proporcionar-lhe, com nossas 
convincentes palavras, dois grandes benefícios: aliviá-lo sempre, inclusive de seus eventuais sentimentos de culpa, prometendo-lhe também, algo de bom, de acordo com sua fé. Assim como cabe a cada pessoa o direito às melhores oportunidades de saúde, assim também cada indivíduo deve ter o direito de viver seus últimos dias com o mínimo possível de dor e o máximo possível de dignidade. A caridade, o calor humano e a oração constituem, também, modalidades de terapia, nas fases finais da vida. Por mais materializados que andem os tempos em que vivemos, todo o paciente, principalmente nas fases finais de sua existência, o que ele mais pede é aquele primeiro fundamento da Medicina que nos deixou Paracelso: o amor, o especial amor que rompe ou procura romper aquela solidão espessa e opaca dentro da qual vivemos uma dor individualizada e incomunicável. A ajuda, a cura, o consolo e a compreensão são fatores que rendem testemunho à consciência moral dos médicos.

Prof. Carlos da Silva Lacaz 